\title{
O GÊNERO DUPLICADO
}

Gustavo Bernardo

Recebido 10, abr. 2010 / Aprovado 30, abr. 2010

\section{Resumo:}

O fenômeno estético da metafiç̧ão questiona a identidade da própria ficção. Ele percorre todos os gêneros literários e duplica a estrutura de cada um deles, assim como os personagens o fazem com seus autores e leitores. Essa duplicação cria um efeito perturbador no leitor, como se o levasse a se perguntar não apenas quem ele é mas também o que é a realidade. Veremos esse fenômeno em contos de Julio Cortázar e Mia Couto.

Palavras-Chave: Gênero. Metaficção. Julio Cortázar. Mia Couto 
Uma das perguntas fundamentais do homem em todas as épocas é a pergunta sobre a sua própria identidade: quem sou eu? Essa pergunta é um dos fundamentos da filosofia, mas também da literatura.

A pergunta volta na construção dos personagens, duplos espelhados dos escritores e dos leitores, e no fenômeno estético da metaficção. A metaficção é uma ficção que se pergunta 'quem sou eu' porque se funda na elaboração da própria ficção. Percorrendo de diferentes maneiras todos os gêneros literários, ela duplica a estrutura de cada um deles assim como os personagens o fazem com seus autores e leitores. Quando a ficção perguntase o que é, ela cria um efeito perturbador no leitor, como se o levasse a se perguntar não apenas quem ele é mas também o que é a realidade.

É dessa perturbação e dessa relação perturbadora entre a literatura e a realidade que pretendo tratar. Começo através de uma imagem conhecida (fig. 1).

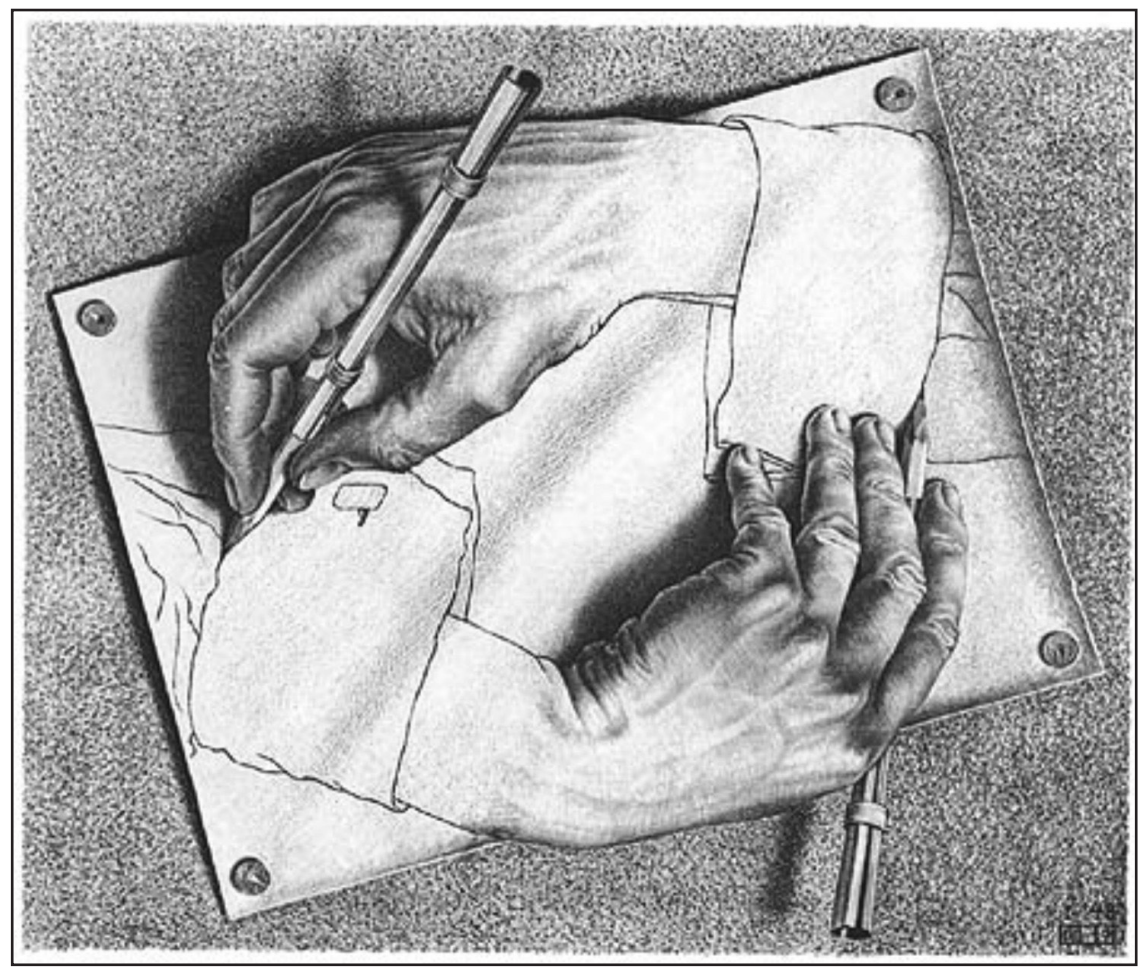

Figura 1

Nessa imagem, a mão esquerda desenha a mão direita que por sua vez desenha a mão esquerda. Duas mãos desenham com zelo uma à outra, aparentemente começando por si mesmas: as mãos já estão tão definidas que parecem sair do próprio desenho que elaboram, e elas agora se dedicam a preparar os punhos da sua camisa (como se só então começassem a desenhar o dono delas mesmas). $O$ desenho dessas mãos encontra-se pregado por tachinhas num pedaço de cortiça - mas o pedaço de cortiça que 
sustenta o desenho é ele mesmo um outro desenho. As mãos que se desenham não estão completas, se ainda não terminaram de se desenhar, mas ao mesmo tempo compõem um quadro completo.

As mãos que desenham a si mesmas remetem a paradoxos importantes, como o de representar a complexidade através de uma ideia visual simples. Elas compõem a litogravura chamada, em holandês, de "Tekenenden handen" - em português, "Mãos que se Desenham". A litogravura foi concebida em 1948 pelo artista holandês Maurits Cornelis Escher (1898-1972), mais conhecido com M. C. Escher.

"As mãos de Escher", como também são chamadas, nos apresentam o enigma da metaficção. Essa ficção peculiar promove uma separação entre a linguagem e a realidade, isto é, explora a ideia de que a linguagem não representa ou "diz" a realidade, mas antes a inventa ou a reinventa.

A metaficção existe desde a primeira narrativa. O coro e o "deus ex machina" das tragédias gregas são soluções metaficcionais. Há quatrocentos anos atrás, o personagem Dom Quixote já criticava a narrativa das histórias de... Dom Quixote. Podemos defini-la como uma ficção que explicita sua própria condição de ficção. Ela não esconde que o é, obrigando o leitor a manter a consciência clara de estar lendo um relato ficcional e não um relato "verdadeiro" - obrigando o leitor, portanto, a manter-se em suspenso, ou seja, em estado permanente de dúvida e incerteza.

Através da metaficção, percebemos que a obrigação da ficção não é a de dizer a verdade mas sim a de firmar uma verdade - diferença sutil, mas importante. $\mathrm{O}$ ato de "dizer a verdade" supõe uma e somente uma verdade prévia à ação de expressá-la, enquanto que o ato de "firmar uma verdade" supõe uma verdade possível entre outras, verdade esta que se constrói no momento mesmo em que se a expressa.

Nas palavras ligeiramente jocosas de William Gass, "a verdade, eu estou convencido, sente antipatia pela arte. É melhor quando um escritor tem uma profunda e persistente indiferença por ela, embora como pessoa a verdade possa ser vital para ele" (Gass, 1958: 8 - truth, I am convinced, has antipathy for art. It is best when a writer has a deep and abiding indifference to it, although as a private person it may be vital to him).

A verdade "mesma" é cinzenta, sensaborosa e, em última análise, inacessível, ao passo que a verdade do escritor é colorida, suculenta e intensa: "isso ilustra um princípio básico: se eu descrevo muitíssimo bem o meu pêssego, é o poema que fará a minha boca aguar... enquanto o pêssego real se estraga" (Gass, 1958: 32 - this illustrates a basic principle: if I describe my peach too perfectly, it's the poem which will make my mouth water... while the real peach spoils).

A ficção que chama a atenção sobre a sua própria condição ficcional termina por levantar questões relevantes sobre as 
relações entre ficção e realidade e, em última análise, questões decisivas sobre a realidade mesma. De acordo com Patricia Waugh, "ao criticar seus próprios métodos de construção, tais escritos não examinam apenas as estruturas fundamentais da ficção narrativa, eles também exploram a possível condição ficcional do mundo externo ao texto ficcional" (Waugh, 1984: 2 - in providing a critique of their own methods of construction, such writings not only examine the fundamental structures of narrative fiction, they also explore the possible fictionality of the world outside the literary fictional text).

A reflexão teórica sobre a literatura se amplia, nesse caso, para uma reflexão filosófica sobre o mundo e a nossa existência nele.

Entre os esquemas metaficcionais, encontramos: romances sobre uma pessoa escrevendo um romance; contos sobre uma pessoa lendo um conto até se ver de repente dentro do conto que está lendo; histórias que comentam as convenções da própria história, como capítulos, títulos, parágrafos ou enredos; romances não-lineares que possam ser lidos não apenas do princípio para o final; notas de rodapé que continuam a história enquanto a comentam; romances em que o autor é personagem do seu próprio romance; histórias que conversam com o leitor, antecipando, frustrando ou ironizando suas reações à história; personagens que se preocupam seriamente com a circunstância de se encontrarem em meio a uma história de ficção; trabalhos de ficção que saem de dentro de outros trabalhos de ficção; histórias que incorporam aspectos e referências de teoria ou crítica da literatura; obras que criam biografias de escritores imaginários; enredos que sugerem aos leitores que eles se encontram em mundos tão ficcionais quanto aquele dos enredos.

A metaficção retoma o paradoxo do mentiroso, cuja versão mais antiga é a do cretense que dizia que todos os cretenses são mentirosos. Se ele estivesse dizendo a verdade, estaria mentindo, logo, não estaria dizendo a verdade. Entretanto, se ele estivesse mentindo, estaria dizendo a verdade, logo, não poderia estar mentindo. Pela reconfiguração moderna do paradoxo, um romancista afirmaria, com toda a sinceridade: "todos os romancistas são mentirosos".

É essa mentira-verdade que me interessa. Vejamo-la primeiro no conto "Continuidade dos parques", de Julio Cortázar, na tradução de Remy Gorga Filho:

Começara a ler o romance dias antes. Abandonou-o por negócios urgentes, voltou à leitura quando regressava de trem à fazenda; deixava-se interessar lentamente pela trama, pelo desenho dos personagens. Essa tarde, depois de escrever uma carta a seu procurador e discutir com o capataz uma questão de parceria, voltou ao livro na tranquilidade do escritório que 
dava para o parque de carvalhos. Recostado em sua poltrona favorita, de costas para a porta que o teria incomodado como uma irritante possibilidade de intromissões, deixou que sua mão esquerda acariciasse de quando em quando o veludo verde e se pôs a ler os últimos capítulos. Sua memória retinha sem esforço os nomes e as imagens dos protagonistas; a fantasia novelesca absorveu-o quase em seguida. Gozava do prazer meio perverso de se afastar linha a linha daquilo que o rodeava, e sentir ao mesmo tempo que sua cabeça descansava comodamente no veludo do alto respaldo, que os cigarros continuavam ao alcance da mão, que além dos janelões dançava o ar do entardecer sob os carvalhos. Palavra por palavra, absorvido pela trágica desunião dos heróis, deixando-se levar pelas imagens que se formavam e adquiriam cor e movimento, foi testemunha do último encontro na cabana do monte. Primeiro entrava a mulher, receosa; agora chegava o amante, a cara ferida pelo chicotaço de um galho. Ela estancava admiravelmente o sangue com seus beijos, mas ele recusava as carícias, não viera para repetir as cerimônias de uma paixão secreta, protegida por um mundo de folhas secas e caminhos furtivos. O punhal ficava morno junto a seu peito, e debaixo batia a liberdade escondida. Um diálogo envolvente corria pelas páginas como um riacho de serpentes, e sentia-se que tudo estava decidido desde o começo. Mesmo essas carícias que envolviam o corpo do amante, como que desejando retêlo e dissuadi-lo, desenhavam desagradavelmente a figura de outro corpo que era necessário destruir. Nada fora esquecido: impedimentos, azares, possíveis erros. A partir dessa hora, cada instante tinha seu emprego minuciosamente atribuído. O reexame cruel mal se interrompia para que a mão de um acariciasse a face do outro. Começava a anoitecer.

Já sem se olhar, ligados firmemente à tarefa que os aguardava, separaram-se na porta da cabana. Ela devia continuar pelo caminho que ia ao Norte. Do caminho oposto, ele se voltou um instante para vê-la correr com o cabelo solto. Correu por sua vez, esquivando-se de árvores e cercas, até distinguir na rósea bruma do crepúsculo a alameda que levaria à casa. Os cachorros não deviam latir, e não latiram. O capataz não estaria àquela hora, e não estava. Subiu os três degraus do pórtico e entrou. Pelo sangue galopando em seus ouvidos chegavam-lhe as palavras da mulher: primeiro uma sala azul, depois uma varanda, uma escadaria atapetada. No alto, duas portas. Ninguém no primeiro quarto, ninguém no segundo. A porta do salão, e então o punhal na mão, a luz dos janelões, o alto respaldo de uma poltrona de veludo verde, a cabeça do homem na poltrona lendo um romance.

"Começara a ler o romance dias antes" (Cortázar, 1956: 11 - no original, 13: Había empezado a leer la novela unos días antes). Assim começa o conto. Esse começo nos joga em um bucólico parque que se comunica com outros parques para formar estranhos "parques comunicantes" (que lembram os vasos comunicantes das antigas aulas de ciência). 
Quando lemos a primeira frase do conto, percebemos que há um personagem que é também um leitor: ele estava no meio da leitura de um certo romance. $\mathrm{O}$ conto começa in media res, isto é, no meio dos acontecimentos, assim como o personagem se encontrava no meio da sua leitura. Esse começo sugere que o começo da ação propriamente dita é anterior; nós, os leitores do leitor daquele romance, pegamos a história (e a leitura) pelo meio - ou, como se dizia antigamente, "com o bonde andando" (no caso, com o parque andando).

O título do conto, "Continuidad de los parques", sugere um espaço contínuo e contíguo através do qual um parque se comunica com outro parque. Essa sugestão cria um problema: a ficção de Cortázar contém dentro dela uma outra ficção. A circunstância de nos encontrarmos lendo uma pessoa que também está lendo é perturbadora: parece que somos indiscretos; parece que nosso queixo repousa no ombro de alguém para lermos o que este alguém está lendo. Emerge a sensação desagradável de que outrem também possa ler o que estamos lendo, ou seja, de que outrem possa estar com o seu próprio queixo pousado no nosso ombro.

Até agora, temos pelo menos três leitores: [1] aquele que lê o conto dentro do conto; [2] cada um de nós quando lê o homem que lê o conto dentro do conto; [3] um possível leitor fantasma que nos lê enquanto lemos o homem que lê o conto dentro do conto.

A sucessão de indiscrições se interrompe por aí? Não, nada garante que pare. "Acima" pode haver um quarto leitor, assim como "abaixo" pode haver um quinto leitor - então, por que não um sexto, um sétimo ou mais leitores, "acima" e "abaixo"? Essa multiplicação de leitores e leituras afeta a continuidade dos parques, transformando-a em uma multiplicação infinita de parques e de lugares. Encontramos uma série possivelmente infinita de mãos de Escher.

Na sequência da leitura percebemos que o personagem (que continua a ler o seu romance) é um homem rico. Ele vive numa "herdade", que em espanhol significa uma grande propriedade rural herdada da família. Sua casa é cercada por um parque de carvalhos - o primeiro parque do título. Ele encontra-se sozinho na biblioteca, sentado na sua poltrona preferida, a de veludo verde. Senta-se de costas para a porta para afastar possibilidades de intrusão ou interrupção da leitura.

Assim que a recomeça, "la ilusión novelesca" o ganha imediatamente: "palavra por palavra, absorvido pela trágica desunião dos heróis, deixando-se levar pelas imagens que se formavam e adquiriam cor e movimento, foi testemunha do último encontro na cabana do monte" (Cortázar, 1956: 11 - no original, 13: palabra a palabra, absorbido por la sórdida disyuntiva de los héroes, dejándose ir hacia las imágenes que se concertaban y adquirían color y movimiento, fue testigo del último encuentro en la cabaña del monte). 
Lemos o leitor que lê sobre o encontro na cabana no meio de um outro parque de carvalhos. Os personagens são uma mulher e seu amante. No peito do homem, aperta-se o punhal destinado a tirar a vida do marido da mulher. Para ambos o punhal representa não morte mas esperança, a possibilidade de viverem livremente o seu amor. Tudo indica que o leitor da poltrona de veludo verde adotou a perspectiva do casal, preparando-se ele mesmo para cometer junto com o amante o assassinato do marido abominável.

O "diálogo envolvente corria pelas páginas como um riacho de serpentes" (Cortázar, 1956: 12 - no original, 14: un diálogo anhelante corría por las páginas como un arroyo de serpientes), a indicar uma legião de demônios: as palavras que os amantes trocam entre si. Enquanto a acompanha, o homem percebe junto com o casal que "todo estaba decidido desde siempre", ou seja, que aquela história está escrita, restando-lhe apenas segui-la com seu prazer de leitor. Mesmo as "caricias que enredaban el cuerpo del amante" esboçam a figura do outro corpo que é necessário destruir: o corpo do marido impertinente, inconveniente e inoportuno.

Os amantes enfim se separam na porta da cabana: ela se afasta para o outro lado enquanto ele se dirige para a casa. À medida que se aproxima da casa, percebe que tudo corre conforme o previsto: "os cachorros não deviam latir, e não latiram. O capataz não estaria àquela hora, e não estava" (Cortázar, 1956: 12 - no original, 14: Los perros no debían ladrar, y no ladraron. El mayordomo no estaría a esa hora, y no estaba).

A mão invisível do narrador (que se confunde com o leitor da poltrona de veludo, leitor este que por sua vez se confunde conosco, leitores do conto de Cortázar) cala os cães da propriedade e garante a ausência do capataz. O amante sobe os degraus da varanda e entra na casa, confirmando a orientação da mulher: primeiro uma sala azul, depois uma varanda, então uma escadaria atapetada. No alto, duas portas: ninguém no primeiro quarto, ninguém no segundo quarto. Finalmente, o momento derradeiro: a última frase do conto.

Por cima do ombro do leitor da poltrona de veludo, nós a lemos: "A porta do salão, e então o punhal na mão, a luz dos janelões, o alto respaldo de uma poltrona de veludo verde, a cabeça do homem na poltrona lendo um romance" (Cortázar, 1956: 13 - no original, 14: La puerta del salón, y entonces el puñal en la mano, la luz de los ventanales, el alto respaldo de un sillón de terciopelo verde, la cabeza del hombre en el sillón leyendo una novela).

O conto termina antes que o assassino apunhale o homem que está lendo a novela de um assassino que irá matar o marido da sua amante enquanto ele está lendo a novela de um assassino que irá matar o marido da sua amante enquanto ele está lendo a novela de um assassino que irá matar...

Ad infinitum. 
Ad nauseam.

Se o homem da poltrona de veludo se confunde necessária e metonimicamente com cada leitor do conto de Cortázar, então nós como leitores somos jogados dentro desse círculo infinito tão fascinante quanto nauseante. A história continua na leitura da história que, por sua vez, continua na leitura da história dentro da história: um parque de carvalhos e palavras se comunica com o outro parque de carvalhos e palavras. Podemos dizer que a leitura da leitura que o personagem realiza na sua poltrona estabelece uma comunicação (que não deveria ser possível) entre a ficção e a realidade. No entanto, se a realidade de que trata o conto é a realidade deste personagem, ora, ela também é fictícia. Logo, se há comunicação, ela se dá entre diferentes níveis de ficção.

A ponte entre esses níveis diferentes de ficção tem o nome de "metaficção". É uma ponte interna, e nela se pensa a ficção dentro da ficção. Por ser interna, podemos substituir a metáfora da ponte pela metáfora das escadas - por exemplo, as escadas de Escher, que vemos na litografia "Relatividade", de 1953 (fig. 2).

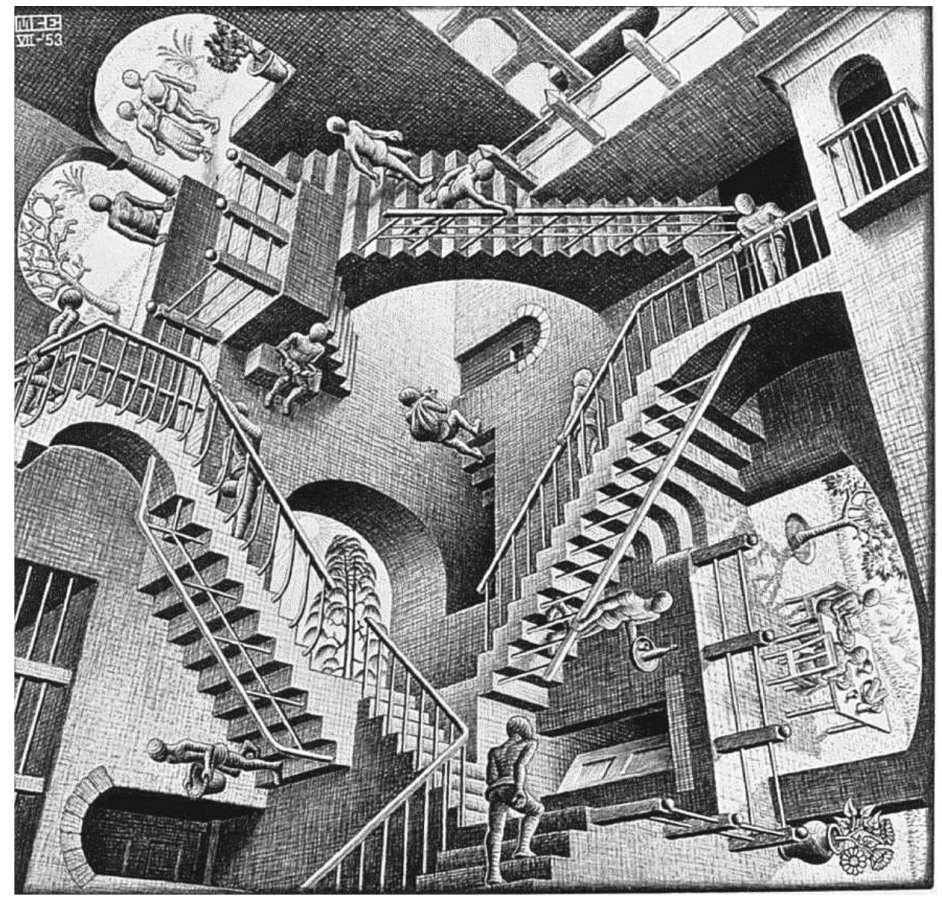

Figura 2

Nas duas dimensões da imagem, Escher nos apresenta mais do que três dimensões, por paradoxal que isso possa parecer. Ele nos obriga a não descansar os olhos, como se não conseguíssemos ver o quadro que, no entanto, vemos.

Suas escadas também representam a metaficção: estabelecem a comunicação entre campos ficcionais. Se aceitarmos que a realidade como a conhecemos não deixa de ser um outro campo de ficções, precisamos aceitar o convite implícito nas escadas de 
Escher: dar mais um passo (para cima ou para baixo?) e esboçar a hipótese de que só podemos passear no parque da realidade se e somente se entramos no parque da ficção.

Ou: de que nós só podemos conhecer a realidade através da ficção. A metaficção representa esse conhecimento e constitui assim uma espécie de metáfora da própria consciência, que não será jamais linear mas sempre labiríntica.

Vejamos agora uma ocorrência diferente de metaficção, no conto "Os machos lacrimosos", de Mia Couto:

Eles se encontravam por causa de alegrias. No bar de Matakuane, os homens anedotavam, fabricando risadas. Um único móbil: festejavam a vida. As suas esposas não suportavam aquele disparatar. Afinal, elas, as mulheres, não precisam de ritual para festejar a vida. Elas são a festa da vida. Ou a vida em festa? Para elas, aquela cumplicidade masculina era coisa de tribo. Reminiscência atávica.

Mas os homens não se importavam. Fosse atávico e tribal, eles mantinham o cerimonial. Cada um que chegava ao bar disparava, logo à entrada:

\section{- Sabem a última?}

E assim se produziam eles, se consumiam elas. Até que sucedeu a noite em que Luizinho Kapa-Kapa, o grande animador dos encontros, trouxe a notícia tristonha. Estava-se em lua muito minguante e ali, na esplanada, pela primeira vez, os copos ficaram cheios toda a noite. É que Luizinho foi desenrolando a história com voz acabrunhada. Antes de chegar ao busílis do relato, quem sabe um irreversível falecimento, Kapa-Kapa cascateou-se em pranto. E os amigos, copo suspenso, em redor da mesa:

\section{- Então, Kapa-Kapa, como é que é?}

Até o musculoso e calado estivador Silvestre Estalone ajudava a animar o lamentoso:

- Verticaliza, homem, verticaliza.

Mas o choroso todaviou-se. E foi crescendo de choraminguado para carpideiro. Entre soluços, soltava os fios da fúnebre narrativa. Já nem se percebia palavra, tal maneira as falas vinham envoltas em babas. Na sala surgiu um lenço e rodou de mão em mão, coletando excessos. Tarde de mais: as chamas da tristeza já haviam devorado o coração de Kapa-Kapa.

Desistiram de o consolar. Amolecidos, os amigos foram-se rendendo a um descaimento no peito, o singelo peso da lama na alma. Fosse isso a tristeza. E chegou mesmo a escorrer, dissimulata, uma lágrima no rosto barbudo do dono do estabelecimento. 
No dia seguinte, quando se sentaram no bar, ainda foi disparado um gracejo: sabem a última? Mas o homem logo se arrependeu: o que ele estava a dar era um ar de sua desgraça. A melancolia se instalara como toalha sobre a mesa. Silvestre Estalone ainda insistiu com nova graça. Mas ninguém riu. Estava-se mais interessado em escutar os novos capítulos da tristeza.

E pediram a Luizinho Kapa-Kapa: ele que divulgasse mais detalhes, rasgando véus, desocultando destinos. E o Luizinho desfez-se na vontade: o drama se desfolhou, ante o olhar lacrimoso dos presentes. Não tardou que todos chorassem babas e rebanhos.

E foi sucedendo uma e outra noite. Uma e outra rodada de tristeza. Os baristas de Matakuane foram deixando a piada e o riso. E passaram a partilhar lamentos, soluços e lágrimas. E até Silvestre Estalone, o mais macho e sorumbático da tribo, acabou confessando:

- Nunca eu pude imaginar, malta. Mas como é bom chorar!

Chorar, mas chorar junto, acrescentaram os outros. E até um se lembrou de propor uma associação de choradores. Pudessem mesmo substituir as profissionais carpideiras dos velórios. Mas os restantes se opuseram, firmes. Afinal, ainda restava neles o fundo preconceito macho de que lágrima pública é coisa para o mulherido.

E foi sucedendo tão devagar que nem parecia acontecer. Ocorria, porém, que os antigos anedoteiros passaram a mudar de trato com o mundo. Aos primeiros sinais do anoitecer lá um declarava ter que regressar a casa.

- Para ajudar a minha gente - confessava, meio envergonhado.

E um outro declinava a insistência de mais uma bebida.

- Não quero que a minha patroa se zangue - justificava.

- Quem quer bebida, pede medida - proverbiavam todos.

E mesmo o Silvestre, que era quem sempre fechava o bar, apelava para que olhassem o relógio. Voltassem todos aos seus lares, convidava o ex-boémio.

- Sim, vamos para nossas casas. Mas não sem derramarmos mais uma lágrima.

- Sim, sai uma para o caminho.

E lá vinha mais história de puxar lustro à tristeza. Que chorar era coisa de maricas, isso já nenhum se lembrava. Nos arredores do bar, a noite se adoçava, escutando-se o suave soluçar 
da rapaziada.

As mulheres até recearam ao ver tanta mudança: seus homens, inexplicavelmente, se revelavam mais delicados e atenciosos. E palavras, flores, carinhos: tudo isso elas passaram a receber. Mordedura de mosca, repentina mudança de idade? E acertaram nem sequer perguntar. Aquilo era tão bom, tão inverossímil, que o melhor era deixar dormir a poeira.

Hoje quem passa pelo bar de Matakuane pode certificar: chorar é um abrir do peito. O pranto é o consumar de duas viagens: da lágrima para a luz e do homem para uma maior humanidade. Afinal, a pessoa não vem à luz logo em pranto? O choro não é a nossa primeira voz?

E é o que, por outras palavras, sentencia Kapa-Kapa: a solução do mundo é termos mais do nosso ser. E a lágrima nos lembra: nós, mais que tudo, não somos água?

Se todo texto literário contém a sua própria teoria, só nos cabendo desentranhá-la das entrelinhas, o conto de Mia Couto explicita com todos os esses e erres suas teorias, tanto sobre a catarse quanto sobre o melodrama.

Em tom quase de crônica de jornal, atravessado pelos habituais neologismos do autor e vários trocadilhos divertidos, conta-se uma história aparentemente singela e ingênua sobre o próprio poder de se contarem histórias ingênuas e singelas. Nesse sentido, o conto é duplamente metaficcional: porque se dobra sobre o seu próprio tema e porque desenvolve uma dupla teoria da narrativa.

No cenário do bar de Matakuane, reconhecemos um legítimo "boteco" brasileiro, ainda que a história não se passe no Brasil. Os nomes dos personagens misturam nomes tribais e apelidos tirados dos filmes americanos mais populares.

Luizinho Kapa-Kapa, por exemplo, mistura o diminutivo, que pode ser tanto carinhoso quanto pejorativo (se pensamos nos "machos" do título e do bar), com o sobrenome de guerra: aquele que capa, portanto castra, duas vezes! Silvestre Estalone, por sua vez, é alusão óbvia aos personagens hiper-machões do ator Sylvester Stallone, em especial Rocky e Rambo.

Essa conjunção dos elementos da cultura e mesmo da doxa popular, característicos do patriarcalismo tanto de Moçambique quanto do Brasil, é desconstruída pela história através justamente da teoria da catarse. Os neologismos de Mia Couto, às vezes excessivos como já o eram os de sua principal inspiração, o escritor brasileiro João Guimarães Rosa, funcionam muito bem nesse conto porque reforçam sempre a sua ironia, responsável pela desconstrução da ideologia do machismo, ideologia esta, por sua vez, pilar de toda ideologia imperialista.

No começo, os personagens se encontram no bar "por causa de alegrias". De triste, basta a vida, diz o vulgo. É preciso rir e 
comemorar, ou mesmo "bebemorar" (este neologismo talvez seja mais propriamente brasileiro). Se pudéssemos entrar no bar ou no conto e perguntar a eles que filme preferem ver, sem dúvida apontariam, primeiro, os de ação, e depois, os que fizessem rir, ou seja, as comédias.

Não sabemos o que Aristóteles disse a respeito da catarse através do riso, porque o seu suposto tratado sobre o cômico se teria perdido. Mas a nossa experiência de espectadores e de leitores nos sugere que a alegria não é, como parece, um sentimento integrador.

O riso do bêbado no bar, que depois de um certo tempo sempre se transforma em choro convulsivo, mostra que a alegria pode ser, ao contrário, desintegradora - até porque via de regra o cômico parte de uma violência ou de um preconceito.

A situação cômica padrão é a da velhinha escorregando na casca de banana e caindo sentada numa poça d'água. De fato, a cena é muito engraçada - menos para ela, decerto, que talvez tenha fraturado o quadril e venha a falecer por conta das complicações derivadas da queda. Nós rimos da velhinha, ou de quem quer que tenha caído, em parte porque não fomos nós a cair, que alívio, em parte deixando escapar nossa agressividade instintiva contra o outro. Em consequência, o sentimento que sucede ao riso não é tão agradável quanto ele, misturando-se o alívio (da raiva liberada) à culpa (pela insensibilidade demonstrada para si mesmo).

A tristeza, ao contrário, por mais depressiva que pareça, nos deixa com a sensação de que por um instante podemos ser melhores do que de fato somos. A tristeza advinda da fruição de uma obra de arte, então, nos torna muito melhores do que somos, porque exercitamos sem peias e sem constrangimentos $o$ raro sentimento da compaixão. Essa sensação integradora, essa sensação de finalmente sabermos quem somos e, ainda, que não somos maus, empresta todas as condições para reflexões calmas sobre nossa identidade, sobre o mundo, sobre o cosmos, quiçá sobre a divindade.

Nesse sentido, a tristeza se torna condição sine qua non do próprio pensamento, vale dizer, da própria filosofia.

É o que os personagens do bar descobrem, surpreendidos e encantados, a partir de uma história tristíssima contada por Luizinho Kapa-Kapa. Quando Luizinho conta uma história tão triste que chega a "todaviar-se", chorando como um carpideiro, diria melhor, como uma carpideira, os "baristas" de Mia Couto descobrem um prazer que não conheciam: o prazer de chorar. Mas, mais do que o prazer de chorar, descobrem o prazer inenarrável de "chorar junto", isto é, de fazerem da experiência um ritual coletivo. Ouvir e contar histórias, de preferência bem tristes, logo se torna uma espécie de culto sagrado daquele grupo. 
A tristeza compartilhada provoca prazer da mesma forma que o fogo gera a água, isto é, que "as chamas da tristeza" provocam rios de lágrimas em todos os presentes. Eles aprendem a elogiar, mais do que as antíteses, os paradoxos em que se percebem mergulhados.

Homeopaticamente, a catarse das narrativas tristes purga os maus humores, expelindo-os junto com as lágrimas. Desta forma, todos se tornam melhores do que eram: preocupam-se com a família, preocupam-se com as mulheres, logo, ocupam-se dos afetos que justificam as suas vidas.

Ao fazê-lo podem, através do discurso indireto livre do narrador, filosofar, reconhecendo que "chorar é um abrir do peito" e que "o pranto é o consumar de duas viagens: da lágrima para a luz e do homem para uma maior humanidade". Nas palavras existencialistas de Kapa-Kapa, aquele que algum dia castrou-castrou: "a solução do mundo é termos mais do nosso ser".

Se o nosso ser é essencialmente água, essencialmente líquido, essencialmente devir, porque escorre pelos dedos como as lágrimas pelas faces, ele só se deixa apreender integrado e integralmente quando choramos com o outro e pelo outro.

Como diz Mia Couto numa belíssima imagem, "a melancolia se instalara como toalha sobre a mesa" justo para permitir a narrativa, o encontro consigo mesmo, o encontro com outro e, por fim, a filosofia.

Como queríamos demonstrar: o gênero duplicado através da metafiç̧ão promove aquela reviravolta aninhada no pensamento que termina por devolvê-lo a si mesmo.

\begin{abstract}
:
The aesthetic phenomenon of metafiction calls in question the identity of fiction itself. Metafiction goes through all literary genres and duplicates the structure of each one, like the fictitious characters do with theirs authors and readers. That duplication creates a disturbing effect to the readers, as if it leads them to question themselves not only who they are but also what is reality. We will see this phenomenon in short stories written by Julio Cortázar and Mia Couto.
\end{abstract}

Keywords: Genre. Metafiction. Julio Cortázar. Mia Couto.

\title{
Referências
}

BOOTH, Wayne C. (1961). The Rhetoric of Fiction. Chicago: The University of Chicago Press, 1983.

CERVANTES, Miguel de (1605-1615). Don Quijote de La Mancha. Madrid: Galaxia Gutenberg, 2005. 
CHALUB, Samira (1998). A metalinguagem. São Paulo: Ática, 2005. CORTÁZAR, Julio (1956). Final del juego. Buenos Aires: Alfaguara, 1993.

(1956). Final do jogo. Tradução de Remy Gorga Filho. Rio de Janeiro: Expressão e Cultura, 1974.

COUTO, Mia (2004). O fio das missangas: contos. São Paulo: Companhia das Letras, 2009.

CURRIE, Mark (org) (1995). Metafiction. New York: Longman. GASS, William H. (1958). Fiction and the Figures of Life. New Hampshire: Nonpareil Books, 2000.

GOMES, Helder (2008). "Metaliteratura". In: Ceia, Carlos (org). E-Dicionário de Termos Literários: em http://www.fcsh.unl.pt/ edtl/verbetes/M/metaliteratura.htm; consultado em dezembro de 2008.

HOFSTADTER, Douglas R. (1979). Gödel, Escher e Bach: um entrelaçamento de gênios brilhantes. Tradução de José Viegas Filho. Brasília: EdUNB, 2001.

KRAUSE, Gustavo Bernardo (2010). O livro da metaficção. Rio de Janeiro: Tinta Negra Bazar Editorial.

PRINCE, Gerald (1982). “Metanarrative signs”. In: CURRIE, Mark (org). Metafiction. New York: Longman, 1995.

SCHOLES, Robert (1970). "Metafiction”. In: CURRIE, Mark (org). Metafiction. New York: Longman, 1995.

WAUGH, Patricia (1984). Metafiction: the Theory and Practice of Self-Conscious Fiction. London: Routledge, 2003. 